\title{
SUPEROXIDE AND PEROXYNITRITE PRODUCTION IN GASTRIC MUCOSA OF RATS UNDER COMBINED NITRATE-FLUORIDE INTOXICATION
}

\author{
Akimov0.Ye.(riseofrevan5@gmail.com),KostenkoV.O. (patofiziolog@umsa.edu.va) \\ Higher State Educational Institution of Ukraine "Ukrainian medical stomatological academy", \\ Poltava, Ukraine
}

The aim of the research is to study influence of combined nitrate-fluoride intoxication on the production of peroxynitrite (ONOO-) and superoxide anion radical (O2-) in gastric mucosa of rats.

Material and methods. We carried out experiments on 52 mature rats. Intoxication was modeled by intragastric administration of sodium fluoride and nitrate in a dose of $10 \mathrm{mg} / \mathrm{kg}$ and $500 \mathrm{mg} / \mathrm{kg}$ respectively. Total production of O2--, ONOO- and concentration of thiobarbituric acid reactants (TBA-reactants) was determined in $10 \%$ homogenate of gastric mucosa.

Results. We observed the highest ONOO-production from fluoride intoxication, while O2•-production was the highest under combined intoxication. The TBA-reactant concentration was the highest in fluoride intoxication group.

Conclusion. Combined nitrate-fluoride intoxication intensifies lipid peroxidation by increased production of both O2•- and ONOO-.

Keywords: nitrates, fluorides, peroxynitrite, reactive oxygen species.

\section{Introduction}

The groundwater pollution has become critical in recent years due to agricultural over application of fertilizers, various salts to increase crop production. The ammonium nitrate, potassium nitrate, sodium nitrate can serve as examples of such fertilizers. Excess concentrations of nitrates in groundwater can result in the shifts in its mineral composition, can replace chloride ions from their sodium salts and reduce the concentration of calcium ions. There are a number of reports devoted to negative effects produced by nitrate intoxication on the functioning of antioxidant enzymes that intensifies the processes of peroxidation of biological polymers $[1,2]$.

Another, not less dangerous, the pollutant of water resources is fluorine. Fluoride can enter groundwater with mineral compounds or wastes, formed during aluminum production or various types of steel. Fluoride ions, like nitrate ions, can enhance the processes of lipid peroxidation and reduce the activity of antioxidant enzymes [3-6].

Ukraine has some areas with a high content of fluoride in ground water. Poltava, Lviv and Kirovograd regions can be classified as such areas also known as the most promising from the point of view of intensive agriculture. Accordingly, in these areas, there is the possibility of simultaneous effects produced by two potentially dangerous factors nitrates and fluorides - on the humans and animals. An intake of excessive amounts of nitrates and fluorides with water primarily affects the metabolic processes in the gastric mucosa. In our previous works, we investigated changes in the functioning of the nitric oxide cycle that enabled us to establish a decrease in the peroxynitrite pool under nitrate intoxication and its increase under combined nitratefluoride intoxication [7]. Peroxynitrite $\left(\mathrm{ONOO}^{-}\right)$is considered to be a major agent leading to nitrosylation of proteins and increase in lipid peroxidation. Peroxynitrite is formed under physiological conditions during inflammatory process in order to provide the body with antimicrobial protection. There is little information available on sources of
$\mathrm{ONOO}^{-}$production in rats' gastric mucosa during combined excessive intake of both fluorides and nitrates.

The aim of the research is to study influence of combined nitrate-fluoride intoxication on the production of $\mathrm{ONOO}^{-}$and superoxide anion radical $\left(\mathrm{O}_{2}^{-}\right)$in gastric mucosa of rats.

\section{Material and methods}

The study was carried out on 52 white rats of the Wistar line (180-220 g) kept under standard conditions. The animals were divided into 4 groups: the first was made up of intact animals $(n=10)$ which received intragastrically $1 \mathrm{ml}$ of distilled water, the second included animals on which we modeled fluoride intoxication by administering $10 \mathrm{mg} / \mathrm{kg}$ sodium fluoride intragastrically via special probe once a day before feeding for 30 days $(n=13)$. The third group, the nitrate intoxication group, consisted of 14 animals, which received a solution of 500 $\mathrm{mg} / \mathrm{kg}$ of sodium nitrate for 30 days. The fourth group was made up by animals that simultaneously received nitrate and sodium fluoride at doses of $500 \mathrm{mg} / \mathrm{kg}$ and $10 \mathrm{mg} / \mathrm{kg}$, respectively $(\mathrm{n}=15)$ for 30 days. Doses of nitrates and fluorides used in modeling chronic intoxications were developed by the department of Pathophysiology of Ukrainian medical stomatological academy [9]. The exact dosage was chosen depending on animals' body weight. Maximal volume of infusion was no more than $1 \mathrm{ml}$ per day to avoid stomach overstretching. The animals were killed by withdrawing blood from the right atrium under thiopental anesthesia. All manipulations with animals were carried out in accordance with the "European Convention for the Protection of Vertebrates used for research and other scientific purposes". All manipulations with animals were approved by bioethical committee of Ukrainian medical stomatological academy (Protocol № 141 from 7.09.2016).

Biochemical studies were carried out immediately after removing animals from experiment in $10 \%$ homogenate of the gastric mucosa. The gastric 
mucosa was removed from underlying layers with the scalpel and was rinsed with $0.9 \%$ sodium chloride solution. Then it was homogenized with 0.1 $\mathrm{M}$ Tris-buffer $(\mathrm{pH}=7.4)$ in cold to obtain $10 \%$ tissue homogenate.

In this study we determined basic level of the superoxide radical anion $\left(\mathrm{O}_{2}{ }^{-}\right)$production spectrophotometrically by the formation of diformazan in the reaction of $\mathrm{O}_{2}^{--}$with tetrazolium nitro blue (TNB) after a 30 -minute incubation in a buffer solution containing in 1 liter $5.37 \mathrm{~g}$ of anhydrous monosodium phosphate, $8.5 \mathrm{~g}$ of sodium chloride and $1.5 \mathrm{~g}$ of sodium hydroxide $(\mathrm{pH}=7.4)$ and in presence of inductors such as $0.1 \mathrm{ml}$ of a $3 \%$ aqueous solution of $\mathrm{NADH}^{+}\left(\mathrm{H}^{+}\right)$and $0.1 \mathrm{ml}$ of $3 \%$ aqueous solution of $\mathrm{NADPH}^{+}\left(\mathrm{H}^{+}\right)$[8].

To determine the sources of $\mathrm{ONOO}^{-}$production we used a modification of existing method [10]. We carried out the determination as follows: in $0.1 \mathrm{ml}$ of $10 \%$ homogenate of the gastric mucosa, the initial concentration of peroxynitrites of alkali and alkalineearth metals was determined by the concentration of $\mathrm{I}_{3}$ - formed in the reaction of $\mathrm{ONOO}^{-}$with potassium iodide (KI). Then, 3 aliquots of $0.1 \mathrm{ml}$ of $10 \%$ tissue homogenate were taken. To first aliquot $0.1 \mathrm{ml}$ of a buffer solution (containing $5.37 \mathrm{~g}$ of anhydrous monosodium phosphate, $8.5 \mathrm{~g}$ of sodium chloride, $1.5 \mathrm{~g}$ of sodium hydroxide in 1 liter) was added; $0.1 \mathrm{ml}$ of a $3 \%$ aqueous solution $(450 \mathrm{nmol})$ of $\mathrm{NADH}^{+}\left(\mathrm{H}^{+}\right)$was added to the second aliquot; 0.1 $\mathrm{ml}$ of $3 \%$ aqueous solution of $\mathrm{NADPH}^{+}\left(\mathrm{H}^{+}\right)$was added to the third aliquot. All three aliquots were incubated for $5 \mathrm{~min}$ at $\mathrm{t}=37^{\circ} \mathrm{C}$. Then $3.8 \mathrm{ml}$ of a phosphate buffer solution $(\mathrm{pH}=7.0)$ and $1 \mathrm{ml}$ of a $5 \%$ solution of potassium iodide were added to each aliquot. Absorption of the corresponding aliquot was determined at a wavelength of 355 (Absorbance of corresponding aliquot, Ax), after which the final concentration of peroxynitrite was calculated in each aliquot according to the formula $\mathrm{Cx}=20 \cdot \mathrm{Ax}$ $\mu \mathrm{mol} / \mathrm{g}$ (where g stands for gram of tissue) [7].

The peroxynitrite production was evaluated using the formulae: basal production $=(\mathrm{C} 1-\mathrm{Cb}) / 300$ $\mu \mathrm{mol} / \mathrm{s}$ per $\mathrm{g}$ of tissue; production of peroxynitrite induced by $\mathrm{NADPH}^{+}\left(\mathrm{H}^{+}\right)=(\mathrm{C} 2-\mathrm{Cb}) / 300 \mu \mathrm{mol} / \mathrm{s}$ per $\mathrm{g}$ of tissue; production of peroxynitrite induced by $\mathrm{NADH}^{+}\left(\mathrm{H}^{+}\right)=(\mathrm{C} 3-\mathrm{Cb}) / 300 \mu \mathrm{mol} / \mathrm{s}$ per $\mathrm{g}$ of tissue. Where C1-3 stand for concentrations of peroxynitrite in 1-3 aliquots after incubation, $\mathrm{Cb}$ is initial concentration of peroxynitrite, 300 is incubation time in seconds. The lipid peroxidation was assessed by measuring thiobarbituric acid reactive substances (TBA-reactants) levels. The quantification was based on measuring formation of TBA-reactants according to the method described by Wills (1969) with modifications made by P. V. Prabhakar et al [6]. All spectrophotometric studies were performed by using an Ulab 101 spectrophotometer.

The results were statistically processed by the Microsoft Office Excel software package and the Real Statistics 2007 extension. The data was checked for dispersion normality by the ShapiroWilk test. We used ANOVA test during normal trait distribution, followed by analysis by Games-Hovel. In the case of a distribution other than normal, the Khruskal-Wallis ANOVA test was used, followed by paired comparisons by Mann-Whitney U test. To avoid effect of multiple comparisons Bonferroni correction was used. Differences between the groups were considered statistically significant if $\mathrm{p}<0,05$.

\section{Results and Discussion}

Fluoride intoxication increases the basic production of $\mathrm{O}_{2}^{--}$by $52.5 \%(\mathrm{p}<0,001$; Table $)$, the base production of $\mathrm{ONOO}^{-}$increases by $44.5 \%$ $(p<0.05)$ compared with control group. Fluoride intoxication does not affect the production of $\mathrm{ONOO}^{-}$induced by $\mathrm{NADH}^{+}\left(\mathrm{H}^{+}\right)$and decreases $\mathrm{NADPH}^{+}\left(\mathrm{H}^{+}\right)$stimulated one by $8.5 \% \quad(\mathrm{p}<0.05)$. However fluoride intoxication increased NADH $\left(\mathrm{H}^{+}\right)$

Table. - Reactive oxygen and nitrogen species production in rats' gastric mucosa $(\mathrm{M} \pm \mathrm{m})$

\begin{tabular}{|l|c|c|c|}
\hline \multicolumn{1}{|c|}{ Parameters } & \multicolumn{3}{|c|}{ Groups } \\
\cline { 2 - 5 } & \multicolumn{1}{|c|}{$\begin{array}{c}\text { Intact } \\
\text { animals, } \mathrm{n}=10\end{array}$} & $\begin{array}{c}\text { Fluoride } \\
\text { intoxication, } \mathrm{n}=13\end{array}$ & $\begin{array}{c}\text { Nitrate } \\
\text { intoxication, } \mathrm{n}=14\end{array}$ \\
intoxication, $\mathrm{n}=15$
\end{tabular}

* - the data are statistically significant different $(p<0.05)$ from the intact group

** - the data are statistically significant different $(p<0.05)$ from the group of fluoride intoxication

$* * *$ - the data are statistically significantly different $(p<0.05)$ from the nitrate intoxication group 
induced production of $\mathrm{O}_{2}^{--}$by $8.5 \%(\mathrm{p}<0,05)$ and $\mathrm{NADPH}^{+}\left(\mathrm{H}^{+}\right)$induced production of $\mathrm{O}_{2}^{--}$by $59 \%$ $(\mathrm{p}<0.05)$.

Nitrate intoxication increases the base production of $\mathrm{O}_{2}^{--}$by $105 \%(\mathrm{p}<0.001)$, but does not affect the base production of $\mathrm{ONOO}^{-}$. Nitrate intoxication reduces the production of $\mathrm{ONOO}^{-}$induced by $\mathrm{NADPH}^{+}\left(\mathrm{H}^{+}\right)$and $\mathrm{NADPH}^{+}\left(\mathrm{H}^{+}\right)$by $20.7 \%(\mathrm{p}<0.05)$ and $10.5 \%(\mathrm{p}<0.05)$, respectively. In the same time $\mathrm{NADH}^{+}\left(\mathrm{H}^{+}\right)$increase production of $\mathrm{O}_{2}^{--}$by $91,83 \%$ $(\mathrm{p}<0.001)$ compared to control group. Induction by $\mathrm{NADPH}^{+}\left(\mathrm{H}^{+}\right)$increases formation of $\mathrm{O}_{2}{ }^{--}$by $39.47 \% \quad(p<0.05)$. Nitrate intoxication increases concentration of TBA-reactants by $46.39 \%(p<0.05)$ compared to control group.

Combined intoxication increases the base production of $\mathrm{O}_{2}{ }^{--}$by $195 \%(\mathrm{p}<0.001)$ compared to the intact group, by $91.8 \%(\mathrm{p}<0.001)$ compared to the fluoride intoxication group and by $43.9 \%(p<0.05)$ compared to the nitrate intoxication that indicates a synergistic effect of nitrates and fluorides on the base production of $\mathrm{O}_{2}^{-}$. Production of $\mathrm{O}^{-}-$in presence of $\mathrm{NADPH}^{+}\left(\mathrm{H}^{+}\right)^{2}$ increases by $11.57 \% \quad(\mathrm{p}<0.05)$ in presence of $\mathrm{NADH}^{+}\left(\mathrm{H}^{+}\right)$by $66.33 \%(\mathrm{p}<0.05)$ compared to control group. $\mathrm{NADPH}^{+}\left(\mathrm{H}^{+}\right)$stimulated $\mathrm{O}^{--}$production during chronic combined nitratefluoride intoxication decreases compared to fluoride intoxication by $29.47 \%(\mathrm{p}<0.05)$ and compared to nitrate intoxication by $19.6 \%$. $\mathrm{NADH}^{+}\left(\mathrm{H}^{+}\right)$ stimulated $\mathrm{O}_{2}{ }^{--}$production during chronic combined intoxication increases by $53.2 \%(p<0.05)$ compared to fluoride and drops by $13.3 \%(\mathrm{p}<0.05)$ compared to nitrate intoxication. The base production of $\mathrm{ONOO}^{-}$ does not statistically significantly change under conditions of combined intoxication compared to fluoride intoxication group, elevates by $22 / 4 \%$ $(p<0.0)$ compared to control and by $26 \%(p<0.05)$ compared to nitrate intoxication. These changes indicate that the main agent inducing peroxynitrite formation under combined intoxication is fluoride. Production of $\mathrm{ONOO}^{-}$induced by $\mathrm{NADPH}^{+}\left(\mathrm{H}^{+}\right)$ increases by $13.2 \%(\mathrm{p}<0.0)$ compared to the intact group, by $23.7 \%(p<0.05)$ compared to the fluoride intoxication group and by $26.5 \%(\mathrm{p}<0.05)$ compared to nitrate intoxication. The $\mathrm{ONOO}^{-}$production induced by $\mathrm{NADH}^{+}\left(\mathrm{H}^{+}\right)$increases by $5.4 \%(\mathrm{p}<0.05)$ compared to the intact group, by $7.9 \%(\mathrm{p}<0.05)$ compared to the fluoride intoxication group and by $32.9 \%(p<0.05)$ compared to nitrate intoxication. The concentration of TBA-reactants during chronic combined nitrate-fluoride intoxication increases by $123.8 \%(p<0.01)$ compared to control group, but drops by $21.3 \%(p<0.05)$ compared to fluoride intoxication. Combined intoxication elevates concentration of TBA-reactants by $52.9 \%(\mathrm{p}<0.05)$ compared to nitrate intoxication.

$\mathrm{NADH}^{+}\left(\mathrm{H}^{+}\right)$is an electron donor formitochondrial electron transport chains (ETC) and $\mathrm{NADPH}^{+}\left(\mathrm{H}^{+}\right)$ is an electron donor for microsomal ETC. Mitochondrial ETC is necessary for production of both $\mathrm{O}^{-}{ }^{-}$and $\mathrm{NO}$ (from cytochromes) [4], necessary for $\mathrm{ONOO}^{-}$formation in mitochondria. Microsomal ETC is necessary for production of $\mathrm{O}_{2}{ }^{--}$and $\mathrm{NO}$ from NOS $[11,12]$. In presence of excessive amounts of electron donors for ETCs there is an increase in their activity, which can lead to $\mathrm{ONOO}^{-}$formation. But in presence of electron donors the production of $\mathrm{ONOO}^{-}$does not increase under fluoride intoxication that allows as exclude mitochondrial and microsomal ETCs as sources of peroxynitrite. Fluorine ions tend to activate the inducible form of NOS, which activity increases, as shown in previous study, this isoform is expressed predominantly in phagocytic leucocytes [7, 11, 12]. The peroxynitrite formed during fluoride intoxication may be viewed as the result of fluoride-induced inflammation. The reactive nitrogen species are necessary as the part of antimicrobial protection during infections. However, during fluoride induced inflammation there are no microbial agents, thus, reactive oxygen and nitrogen species formed by NADPH-oxidase will lead to oxidative and nitrosative stress. We can observe the results of oxidative and nitrosative stress due to increase of TBA-reactant concentration by $86.1 \%$ compared to control group.

Since there are two components necessary for $\mathrm{ONOO}^{-}$formation, an absence of the increase in base peroxynitrite formation under conditions of chronic nitrate intoxication can be explained by insufficient NO formation by NOS. Our previous study showed that during chronic nitrate intoxication NOS activity is reduced while nitrite reductases activity is increased [7]. Peroxynitrite ability to spontaneously isomerize to nitrate and increase in the activity of nitrate reductase, shown in previous study, contributes to a decrease in the total amount of peroxynitrite of alkali and alkaline earth metals under nitrate intoxication $[7,13]$.

The effect of fluoride ions during combined intoxication on $\mathrm{NADH}^{+}\left(\mathrm{H}^{+}\right)$stimulated $\mathrm{ONOO}^{-}$ production can be explained by the increase in the $\mathrm{O}_{2}{ }^{-}$induced by fluoride intoxication and the decrease in the absorption by mitochondria of $\mathrm{O}_{2}$ [14]. This leads to increased generation of one of the necessary products for $\mathrm{ONOO}^{-}$formation. Since cytochromes have nitrate-nitrite reduction ability, they can provide the second necessary product, namely $\mathrm{NO}$ via $\mathrm{NO}_{3}-\mathrm{NO}_{2}-\mathrm{NO}$ reductive pathway [4]. As we have already established the increase in NOS activity in our preceding work, we can suggest that an increase in the production of $\mathrm{ONOO}^{-}$ stimulated by $\mathrm{NADPH}^{+}\left(\mathrm{H}^{+}\right)$is associated with inhibition of the activity of calmodulin-dependent NOS isoforms and activation of the inducible form [7]. Calmodulin-dependent NOS isoforms use microsomal ETC to create spare electron necessary for $\mathrm{NO}^{*}$ production. Since their activity decreases under fluoride ions' influence and the electron transport is not stopped, the spare electron formed in ETC is used for $\mathrm{O}_{2}{ }^{-}$creation. The effectiveness of nitrate-nitrite reductases as a mechanism for neutralizing peroxynitrite (after its isomerization to nitrate) under conditions of combined intoxication is not as effective as in isolated nitrate intoxication.

\section{Conclusions}

Combined nitrate-fluoride intoxication intensifies lipid peroxidation by increased production of $\mathrm{O}^{-}$ and $\mathrm{ONOO}^{-}$. Nitrate intoxication limits $\mathrm{ONOO}^{-}$ production but does not limit lipid peroxidation. 
Fluoride intoxication's tissue damaging agents are $\mathrm{ONOO}^{-}$and $\mathrm{O}_{2}{ }^{\circ}$. Further studies on mechanisms

\section{Литература}

1. Ansari, F. A. Sodium nitrate induces reactive oxygen species that lower the antioxidant power, damage the membrane, and alter pathways of glucose metabolism in human erythrocytes / F. A. Ansari, R. J. Mahmood // Agric Food Chem. - 2015. - Vol. 63 (48). - P. 10372-10379. - doi: 10.1021/acs.jafc.5b04898.

2. Hyparrhenia hirta: A potential protective agent against hematotoxicity and genotoxicity of sodium nitrate in adult rats / H. Bouaziz-Ketata [et al.] // Environ Toxicol. - 2015. - Vol. 30 (11). - P. 1275-1284. - doi: 10.1002/tox.21998.

3. Hamza, R. Z. Protective effects of blackberry and quercetin on sodium fluoride-induced oxidative stress and histological changes in the hepatic, renal, testis and brain tissue of male rat / R. Z. Hamza, N. S. El-Shenawy, H. A. Ismail // J. Basic Clin Physiol Pharmacol. - 2015. - Vol. 26 (3). P. 237-251. - doi: 10.1515/jbcpp-2014-0065.

4. Nitrate and nitrite in biology, nutrition and therapeutics / J. O. Lundberg [et al.] // Nat Chem Biol. - 2009. - Vol. 5 (12). - P. 865-9. - doi: 10.1038/nchembio.260.

5. Nabavi, S. F. Protective effects of curcumin against sodium fluoride-induced toxicity in rat kidneys / S. F. Nabavi, A. H. Moghaddam, S. Eslami // Biol Trace Elem Res. 2012. - Vol. 145 (3). - P. 369-374. - doi: 10.1007/s12011011-9194-7.

6. Oxidative stress induced by aluminum oxide nanomaterials after acute oral treatment in Wistar rats / P. V. Prabhakara [et al.] // J Appl Toxicol. - 2012. - Vol. 32. - P. 436-445. - doi: 10.1002/jat.1775.

7. Akimov, O. Y. Functioning of Nitric oxide cycle in gastric mucosa of rats under excessive combined intake of sodium nitrate and fluoride / O. Y. Akimov, V. O. Kostenko // Ukr Biochem J. - 2016. - Vol. 88 (6). - P. 70-75. - doi: 10.15407/ubj88.06.070.

8. Костенко, В. О. Продукція супероксидного аніон-радикала та оксиду азоту у тканині нирок після хірургічного втручання / В. О. Костенко, О.І.Цебржинський // Фізіологічний журнал. - 2000. - Т. 46, № 5. - С. 56-62.

9. Стасюк, О. А. Вплив скевенджерів пероксинітриту на окиснювальні процеси у тканинах слинних залоз білих щурів за умов спільного надлишкового надходження нітрату та фториду натрію / О. А. Стасюк, В. О. Костенко // Проблемы экологии и медицины. - 2012. - T. 16, № 5-6. - С. 30-33.

10. Шрайбман, Г. Н. Спектрофотометрические методики определения пероксинитрита и нитрита / Г. Н. Шрайбман, Е. П. Дягилева, А. В. Скибина // Вестник Кемеровского государственного университета. -2011. - №. 1 (45). - C. 200-206.

11. Effects of sodium fluoride on immune response in murine macrophages / B. De la Fuente [et al.] // Toxicol In Vitro. - 2016. - Vol. 34. - P. 81-87. - doi: 10.1016/j. tiv.2016.03.001.

12. Chronic fluoride exposure-induced testicular toxicity is associated with inflammatory response in mice / R. Wei [et al.] // Chemosphere. - 2016. - Vol. 153. - P. 419-425. - doi: 10.1016/j.chemosphere.2016.03.045.

13. Дягилева, Е. П. Изомеризация и диссоциация пероксонитрит иона при растворении кристаллического нитрата калия, облученного светом длиной волны 253.7 нм / Е. П. Дягилева, М. Б. Миклин // Вестник leading to tissue damage by combined nitratefluoride intoxication are needed.

Кемеровского государственного университета. -2015 . - T. 3, № 4 (64). - C.233-236.

14. Sodium Fluoride Induces Apoptosis in H9c2 Cardiomyocytes by Altering Mitochondrial Membrane Potential and Intracellular ROS Level / X. Yan [et al.] // Biol Trace Elem Res. - 2015. - Vol. 166 (2). - P. 210-215. - doi: 10.1007/s12011-015-0273-Z

\section{References}

1. Ansari FA, Mahmood RJ. Sodium nitrate induces reactive oxygen species that lower the antioxidant power, damage the membrane, and alter pathways of glucose metabolism in human erythrocytes. Agric Food Chem. 2015;63(48):10372-10379. doi: 10.1021/acs. jafc.5b04898.

2. Bouaziz-Ketata H, Salah GB, Mahjoubi A, Aidi Z, Kallel C, Kammoun H, Fakhfakh F, Zeghal N. Hyparrhenia hirta: A potential protective agent against hematotoxicity and genotoxicity of sodium nitrate in adult rats. Environmental Toxicology. 2015;30(11):1275-84. doi: 10.1002/tox.21998.

3. Hamza RZ, El-Shenawy NS, Ismail HA. Protective effects of blackberry and quercetin on sodium fluoride-induced oxidative stress and histological changes in the hepatic, renal, testis and brain tissue of male rat. J Basic Clin Physiol Pharmacol. 2015;26(3):237-251. doi: 10.1515/ jbcpp-2014-0065.

4. Lundberg JO, Gladwin MT, Ahluwalia A, Benjamin N, Bryan NS, Butler A, Cabrales P, Fago A, Feelisch M, Ford PC, Freeman BA, Frenneaux M, Friedman J, Kelm M, Kevil CG, Kim-Shapiro DB, Kozlov AV, Lancaster JR Jr, Lefer DJ, McColl K, McCurry K, Patel RP, Petersson J, Rassaf T, Reutov VP, et al. Nitrate and nitrite in biology, nutrition and therapeutics. Nat Chem Biol. 2009;5(12):865-9. doi: 10.1038/nchembio.260.

5. Nabavi SF, Moghaddam AH, Eslami S. Protective effects of curcumin against sodium fluoride-induced toxicity in rat kidneys. Biol Trace Elem Res. 2012;145(3):369-374. doi: 10.1007/s12011-011-9194-7.

6. Prabhakar PV, Reddy UA, Singh SP, Balasubramanyam A, Rahman MF, Indu Kumari S, Agawane SB, Murty US, Grover P, Mahboob M. Oxidative stress induced by aluminum oxide nanomaterials after acute oral treatment in Wistar rats. J Appl Toxicol. 2012;32(6):436-445. doi: 10.1002/jat.1775.

7. Akimov OY, Kostenko VO. Functioning of Nitric oxide cycle in gastric mucosa of rats under excessive combined intake of sodium nitrate and fluoride. Ukr Biochem $J$. 2016;88(6):70-75. doi: 10.15407/ubj88.06.070.

8. Kostenko VO. Cebrzhynskyj OI. Produkcija superoksydnogo anion-radykala ta oksydu azotu u tkanyni nyrok pislja hirurgichnogo vtruchannja. Fiziologichnyj zhurnal. 2000;46(5):56-62. (Ukrainian).

9. Stasjuk OA, Kostenko VO. Vpliv skevendzheriv peroksinitritu na okisnjuvalni procesi u tkaninah slinnih zaloz bilih shhuriv za umov spilnogo nadlishkovogo nadhodzhennja nitratu ta ftoridu natriju. Problemy jekologii $i$ mediciny [Problems of ecology and medicine]. 2012;16(56):30-33. (Ukrainian).

10. Shrajbman GN, Djagileva EP, Skibina AV. Spektrofotometricheskie metodiki opredelenija peroksinitrita i nitrita. Vestnik Kemerovskogo gosudarstvennogo 
universiteta [Bulletin of the Kemerovo State University]. 2011;1(45):200-206. (Russian).

11. De la Fuente B, Vazquez M, Rocha RA, Devesa V, Velez D. Effects of sodium fluoride on immune response in murine macrophages. Toxicology in Vitro. 2016;34:81-87. doi: 10.1016/j.tiv.2016.03.001.

12. Wei R, Luo G, Sun Z, Wang S, Wang J. Chronic fluoride exposure-induced testicular toxicity is associated with inflammatory response in mice. Chemosphere. 2016;153:419425. doi: 10.1016/j.chemosphere.2016.03.045.

13. Djagileva EP, Miklin MB. Izomerizacija i dissociacija peroksonitrit iona pri rastvorenii kristallicheskogo nitrata kalija, obluchennogo svetom dlinoj volny $253.7 \mathrm{~nm}$
[Isomerization and dissociation of the peroxynitrite ion formed by dissolving crystalline potassium nitrate irradiated with $253.7 \mathrm{~nm}$ light]. Vestnik Kemerovskogo gosudarstvennogo universiteta [Bulletin of the Kemerovo State University]. 2015;3(4):233-236. (Russian).

14. Yan X, Yang X, Hao X, Ren Q, Gao J, Wang Y, Chang N, Qiu Y, Song G. Sodium Fluoride Induces Apoptosis in $\mathrm{H} 9 \mathrm{c} 2$ Cardiomyocytes by Altering Mitochondrial Membrane Potential and Intracellular ROS Level. Biol Trace Elem Res. 2015;166(2):210-215. doi: 10.1007/ s12011-015-0273-z.

\section{ПРОДУКЦИЯ СУПЕРОКСИДА И ПЕРОКСИНИТРИТА В СЛИЗИСТОЙ ОБОЛОЧКЕ ЖЕЛУДКА КРЫС В УСЛОВИЯХ ХРОНИЧЕСКОЙ НИТРАТНО-ФТОРИДНОЙ ИНТОКСИКАЦИИ \\ Акимов О. Е. , Костенко В. А. \\ Высшее государственное учебное заведение Украины «Украинская медицинская стоматологическая академия», Полтава, Украина}

Целью исследования является изучение влияния сочетанной нитратно-фторидной интоксикации на продукцию пероксинитрита (ONOO-) и супероксидного анион-радикала $\left(_{2}^{-}{ }_{2}^{-}\right.$в слизистой оболочке желудка крыс.

Материал и методы. Мы провели эксперименты на 52 зрелых крысах. Интоксикация была смоделирована путем внутрижелудочного введения натрия фторида и нитрата в дозе 10 мг/кг и 500 мг/кг соответственно. Общую продукцию $\mathrm{O}_{2}^{\circ}$, ОNOO- и конщентращию вещееств, реагирующих с тиобарбитуровой кислотой (ТБК-реактанты), определяли в 10\% гомогенате слизистой оболочки желудка.

Результаты. Мы наблюдали наивысшую продукцию ОNOO- при фтторидной интоксикации, а продукция $\mathrm{O}_{2}{ }^{-}$была самой высокой при сочетанной интоксикаџии. Конџентраџия ТБК-реактантов была самой высокой в группе фторидной интоксикации.

Вывод. Комбинированная нитратно-фторидная интоксикация усиливает перекисное окисление липидов за счет увеличения $\mathrm{O}_{2}^{--}$и ONOO-

Ключевые слова: нитраты, фториды, пероксинитрит, активные формы кислорода. 